E-ISSN : $2580-9180$

ISSN : $2301-461 X$

\title{
Evaluasi Program Pembelajaran Sejarah Terintegrasi dalam Mata Pelajaran IPS Di SMPN 4 Kota Bekasi
}

\author{
Kurniawati dan Zulfiati \\ Dosen Prodi Pendidikan Sejarah UNJ \\ kurniawati204@gmail.com
}

\begin{abstract}
This research explores the history learning which is integrated to IPS subject or also known as social studies at secondary school in SMPN 4 Kota Bekasi. The Method used in this research was evaluation method which employed responsive evaluation developed by Stake. Responsive evaluation by Stake used responsive clock as guided stages for evaluator. There were three components of evaluation following his earlier countenance model antecedent, transactions and outcomes. The things considered as antecedent were policy of the program, goal of the program, curriculum, book, means and infrastructure, and teacher's competency. The things considered as transactions were lessons plan, instructional implementation, assessment, method and media of instructions. The results of the research show that there were several problems in the school related to program being evaluated, therefore several recommendation are given to IPS's teacher, headmaster, government and also parents and community.
\end{abstract}

Keywords: history learning, IPS subject, responsive evaluation

\begin{abstract}
Abstrak: Penelitian ini bertujuan untuk mendeskripsikan pembelajaran sejarah yang terintegrasi dalam mata pelajaran IPS atau yang dikenal juga sebagai social studies di sekolah menengah pertama SMPN 4 Kota Bekasi. Metode yang digunakan dalam penelitian ini adalah metode evaluasi yang menggunakan model evaluasi responsive yang dikembangkan oleh Stake. Evaluasi responsive yang dikembangkan oleh Stake menggunakan responsive clock sebagai panduan bagi evaluator. Terdapat tiga komponen evaluasi mengikuti model countenance yang telah dikembangkan sebelumnya oleh Stake yaitu komponen antecedent, komponen transactions dan komponen outcomes. Termasuk komponen antecedent adalah kebijakan program, tujuan program, kurikulum, buku, sarana prasarana, dan kompetensi guru. Termasuk dalam komponen transactions adalah perencanaan pembelajaran, pelaksanaan pembelajaran, metode pembelajaran, media pembelajaran dan penilaian proses pembelajaran. Hasil penelitian menunjukkan bahwa terdapat beberapa masalah di sekolah berkaitan dengan program pembelajaran sejarah yang terintegrasi dalam mata pelajaran IPS di SMP N 4 Kota Bekasi, sehingga beberapa saran diberikan kepada sekolah dan guru, MGMP, pemerintah, orang tua dan masyarakat.
\end{abstract}

Kata Kunci: pembelajaran sejarah, mata pelajaran IPS, Evaluasi responsive 


\section{PENDAHULUAN}

Pendidikan sejarah merupakan pendidikan yang meliputi tiga landasan utama yaitu landasan politis, landasan filosofis dan landasan akademis. (Hasan, 2012:3). Sejak kurikulum 1975, pelajaran sejarah di tingkat SMP masuk dalam pelajaran Ilmu Pengetahuan Sosial (IPS) bersama-sama dengan geografi, ekonomi dan sosiologi. Pada praktiknya di lapangan banyak guru-guru IPS yang merasa kesulitan karena mereka pada umumnya hanya menguasai salah satu dari pelajaran IPS sesuai dengan latar belakang pendidikannya. Akibatnya pembelajaran IPS bervariasi pelaksanaannya dari yang sepenuhnya terpadu, setengah terpadu dan tidak terpadu. Perubahan kurikulum belum memberikan solusi yang nyata terhadap permasalahan tersebut. Permasalahan-permasalahan yang mengemuka dalam pembelajaran IPS menunjukkan pentingnya penelitian evaluasi dalam pembelajaran sejarah yang terintegrasi dalam mata pelajaran IPS ini dilakukan.

Pembelajaran (instruction) menurut Gagne et.al (2005:1) adalah membantu orang-orang untuk belajar. Belajar dapat saja terjadi tanpa pembelajaran tetapi memakan waktu yang lebih lama karena tidak ada faktor-faktor lain yang membantu pelaksanaan belajar tersebut. Sanjaya (2014:104) mengatakan bahwa pembelajaran adalah usaha siswa dalam mempelajari bahan pelajaran sebagai akibat perlakuan guru. Pembelajaran tidak hanya melibatkan guru saja atau murid saja, tetapi juga menuntut keterlibatan keduanya. Guru mendesain kegiatan belajar-mengajar sehingga semua potensi siswa dapat tergali secara optimal. Arifin (2013:10) mengatakan bahwa pembelajaran adalah suatu proses atau cara yang dilakukan agar seseorang dapat melakukan kegiatan belajar. Menurutnya pembelajaran adalah suatu program yang bercirikan sistematik, sistemik dan terencana. Pembelajaran dengan demikian adalah suatu kegiatan yang dilakukan seseorang dalam kegiatan belajarnya melalui proses interaksi dengan guru di dalamnya. 
Kuntowijoyo (2005:26) mengatakan bahwa sejarah mempunyai guna intrinsik dan ekstrinsik. Jika guna intrinsik lekat dengan sejarah sebagai ilmu maka guna ekstrinsik sejarah sangat lekat dengan dunia pendidikan. Sejarah mempunyai fungsi sebagai sarana pendidikan moral, penalaran, politik, kebijakan, perubahan, masa depan, keindahan dan ilmu bantu. Hasan (2012:68) mengatakan bahwa pembelajaran sejarah adalah suatu proses belajar yang berkaitan dengan manusia dan kemanusiaan. Menurutnya proses pembelajaran sejarah seharusnya dapat mengembangkan kemampuan berpikir kritis siswa sehingga menghasilkan manusia-manusia yang cerdas. Wineburg mengatakan belajar sejarah bermanfaat bagi siswa untuk menjadikannya manusia yang berperikemanusiaan, suatu hal yang tidak dapat dilakukan oleh semua mata pelajaran yang lain. Drake and Nelson (2005:15) mengatakan bahwa pembelajaran sejarah melibatkan ilmu dan seni. Melibatkan ilmu ketika melibatkan pertanyaan-pertanyaan terstruktur, yang telah diinformasikan mengenai masa lalu dan melibatkan seni dalam menjelaskan bagaimana unsurunsur dari masa lalu dapat dihidupkan lagi di masa sekarang padahal siswa paham keunikan sejarah yang tidak dapat terulang lagi. Kartodirdjo (2014:284285) mengatakan bahwa pembelajaran sejarah mempunyai fungsi pragmatis, genetis dan didaktis. Fungsi pragmatis adalah melegitimasi dan justifikasi eksistensi suatu bangsa. Fungsi genetis adalah menerangkan bagaimana sesuatu terjadi, yang berarti melacak genetika atau asal mula suatu peristiwa. Fungsi didaktis adalah pengetahuan sejarah menjadi pelajaran atau dapat diambil hikmahnya oleh generasi selanjutnya. Secara lebih terinci Agung dan Wahyuni (2013:61-63) menjabarkan karakteristik pembelajaran sejarah yaitu pembelajaran yang terkait dengan masa lampau, bersifat kronologis, memuat unsur manusia, ruang dan waktu, mempunyai prinsip sebab dan akibat, berhubungan dengan berbagai aspek kehidupan masyarakat yang multidimensional.

Pembahasan mengenai pembelajaran dan sejarah di atas membawa pada kesimpulan bahwa pembelajaran sejarah adalah proses belajar yang bertujuan 
membangun manusia yang berprikemanusiaan yang melibatkan aspek ilmu dan seni sekaligus, berfungsi pragmatis, genetis dan didaktis.

Sapriya (2014:7) mengatakan bahwa Ilmu Pengetahuan Sosial mempunyai ciri khas yaitu sifat terpadu (integrated) dari sejumlah mata pelajaran dengan tujuan agar dapat lebih bermakna bagi peserta didik sehingga pengorganisasian materi/bahan pelajaran disesuaikan dengan lingkungan, karakteristik dan kebutuhan peserta didik. Susanto (2014:6) mengatakan bahwa Ilmu Pengetahuan Sosial merupakan integrasi dari berbagai cabang ilmu-ilmu sosial dan humaniora yaitu:sosiologi, sejarah, geografi, ekonomi, politik, hukum dan budaya. Rachmah (2015:19-20) IPS mengatakan bahwa IPS merupakan integrasi dari ilmu-ilmu sosial dan humaniti yaitu ilmu ekonomi, geografi, sejarah, hukum, politik, sosiologi, antropologi, filosofi dan psikologi. Lebih lanjut lagi dikatakan bahwa IPS adalah kehidupan sosial di masyarakat sehingga masyarakatlah yang menjadi sumber pembelajaran utama IPS. Tujuan pembelajaran IPS adalah membantu siswa dalam menguasai, memahami dan mengembangkan kemampuan yang berkaitan dengan disiplin ilmu sosial sehingga diharapkan siswa dapat berpikir rasional dan kritis dalam menanggapi isu-isu sosial dan akhirnya dapat membuat keputusan berdasarkan pengolahan informasi yang pada akhirnya dapat berpartisipasi sebagai warga negara. Trianto (2015:171) mengatakan bahwa Ilmu Pengetahuan Sosial (IPS) merupakan integrasi dari berbagai cabang ilmu-ilmu sosial seperti sosiologi, sejarah, geografi, ekonomi, politik, hukum dan budaya. Ilmu pengetahuan sosial dirumuskan atas dasar realitas dan fenomena sosial yang mewujudkan satu pendekatan interdisipliner dari aspek dan cabang-cabang ilmu-ilmu sosial. Disimpulkan bahwa program pendidikan IPS yang dikembangkan di Indonesia sejak 1970an merupakan adopsi dari social studies yang dikembangkan di AS sejak awal abad ke-20. IPS mempunyai tujuan agar siswa atau peserta didik dapat menjadi warga negara Indonesia dan juga warga dunia yang baik, bertanggungjawab dan cinta damai. 
Penelitian yang relevan antara lain penelitian yang dilakukan Abma berjudul Responsive Evaluation Its Meaning and Special Contribution to Health Promotion (2005:279-289). Penelitian Abma ini menggunakan evaluasi responsif yang dikembangkan Stake untuk mengetahui keefektifan injury program pada sekolah seni. Penelitian relevan lainnya adalah penelitian yang dilakukan oleh Agung (2012:145-155) berjudul Implementasi Model Pembelajaran IPS Terpadu (Suatu Studi Evaluatif di SMP Kota Surakarta). Penelitan ini bertujuan untuk mengetahui implementasi model pembelajaran IPS terpadu di SMP Kota Surakarta, yaitu untuk mengidentifikasi faktor-faktor penghambat dan mengetahui upaya-upaya yang dilakukan oleh guru IPS dalam meningkatkan profesionalisme

Penelitian ini bertujuan untuk mendeskripsikan pembelajaran sejarah yang terintegrasi dalam mata pelajaran IPS di SMPN 4 Kota Bekasi yang meliputi aspek efektifitas persiapan (antecedent), proses (transaction) dan hasil (outcome) pembelajaran sejarah yang terintegrasi dalam mata pelajaran IPS.

\section{METODOLOGI PENELITIAN}

Evaluasi responsif dari Stake (1973:20) yang menggunakan tahapantahapan yang disebut sebagai Responsive Clock. Tahapan-tahapan tersebut adalah: talk with client, program staff, audience; identify programs scope; overview program activities; discover purposes, concerns; conceptualize issues; identify data needs related to issues; select observers, judges, instruments, if any; observe designated antecedent, transactions dan outcomes; thematize, prepare portrayals, case studies; validate, confirm, attempt to disconfirm; winnow, match issues to audience; format for audience use.

Pendekatan penelitian ini adalah kualitatif sehingga peneliti menjadi instrumen utama. Suatu kisi-kisi instrumen tetap diperlukan sebagai panduan peneliti di lapangan. Kisi-kisi yang dibuat berdasarkan komponen antecedent, transactions dan outcomes. Terdapat lima aspek yang dievaluasi pada tahapan antecedent yaitu: 1) kebijakan program; 2) tujuan program; 3) kurikulum; 4) buku; 
5) sarana prasarana. Instrumen yang digunakan pada tahapan antecedent adalah observasi, dokumen kurikulum dan dokumentasi.

Pada tahapan transactions terdapat lima aspek yang dievaluasi yaitu: perencanaan pembelajaran, pelaksanaan kegiatan pembelajaran, penilaian hasil pembelajaran, metode pembelajaran, media pembelajaran. Instrumen yang digunakan pada tahapan transactions adalah observasi. wawancara dan dokumentasi. Pada tahapan outcomes terdapat dua aspek yang dievaluasi yaitu: hasil dan dampak. Instrumen yang digunakan pada tahapan outcomes adalah observasi dan wawancara.

Validasi yang dilakukan pada penelitian evaluasi model responsive ini mengikuti validasi untuk penelitian evaluasi responsive yang diajukan oleh Guba dan Lincoln (1981:104) yaitu Truth Value, Applicability, Consistency, dan Neutrality. Teknik dan prosedur pengumpulan data yang digunakan untuk memeroleh data penelitian ini terdiri dari tiga macam yaitu observasi, wawancara dan bahan audiovisual. Selanjutnya data dianalisis dan diinterpretasi melalui proses pengodean, penggunaan kode untuk mengembangkan gambaran yang lebih umum tentang data (deskripsi dan tema), perepresentasian temuan melalui naratif dan visual, pembuatan interpretasi tentang makna hasil dengan perefleksian secara pribadi tentang dampak temuan dan tentang kepustakaan yang mungkin menjelaskan temuannya dan pelaksanaan strategi untuk memvalidasi keakuratan temuannya.

Teknik dan prosedur pengumpulan data yang digunakan untuk memeroleh data penelitian ini terdiri dari tiga macam yaitu observasi, wawancara dan bahan audiovisual. Setelah mengumpulkan data berupa hasil observasi, wawancara dan bahan audiovisual maka data dianalisis. Creswell (2015:468-469) mengatakan ada enam langkah dalam menganalisis dan menginterpretasi data kualitatif yang tidak selalu dilakukan secara berurutan yaitu persiapan dan pengorganisasian data untuk dianalisis, keterlibatan dalam eksplorasi awal data melalui proses pengodean, penggunaan kode untuk 
mengembangkan gambaran yang lebih umum tentang data (deskripsi dan tema), perepresentasian temuan melalui naratif dan visual, pembuatan interpretasi tentang makna hasil dengan perefleksian secara pribadi tentang dampak temuan dan tentang kepustakaan yang mungkin menjelaskan temuannya dan pelaksanaan strategi untuk memvalidasi keakuratan temuannya

\section{HASIL PENELITIAN}

\section{Antecedent}

\subsection{Kebijakan Program}

Bagaimana mata pelajaran IPS dapat diajarkan secara integratif merupakan isu yang mengemuka di SMP Negeri 4 Kota Bekasi. Beberapa guru mengatakan belum mengerti betul konsep integrasi atau terpadu dalam IPS seperti yang dikatakan oleh seorang guru IPS yaitu Ibu SS. Guru IPS lain Ibu NM juga merasa belum jelas dengan konsep integrasi dalam IPS meskipun dikatakan praktiknya sudah dilaksanakan.

Ibu SW mengakui bahwa memang konsep integrasi dalam IPS menjadi satu permasalahan karena seharusnya terintegrasi tetapi pada praktiknya sulit dilakukan. Ibu SW mendengar keluhan dari guru-guru IPS bahwa mereka yang berlatarbelakang geografi misalnya lebih merasa enjoy mengajar geografi karena mereka dapat mengajar bidang tersebut dengan lebih banyak dan lebih detail.

Menanggapi mengenai keintegrasian dalam IPS, Ibu EH mengatakan bahwa untuk meningkatkan mutu justru seharusnya sejarah, geografi, sosiologi dan ekonomi diajarkan secara terpisah dan masing-masing diajar oleh orang yang memang mempunyai latar belakang pendidikan yang sesuai.

Menanggapi isu keintegrasian dalam mata pelajaran IPS, Ibu DS mengatakan bahwa tidak semua materi dapat dipadukan atau diintegrasikan. Ibu DS mencontohkan topik yang tidak dapat dipadukan yaitu kegiatan produksi yang menurutnya mungkin saja dipadukan tetapi Ibu DS sendiri belum memahaminya. 
Khusus mengenai keberadaan integrasi materi sejarah dalam IPS, Ibu SS mengatakan bahwa sebetulnya cocok karena bangsa Indonesia harus mengingat jati dirinya. Menurutnya sejarah penting dan harus ada karena sejarah diperlukan untuk membangkitkan nasionalisme. Nasionalisme menurut Ibu SS adalah faktor yang penting dari pembelajaran IPS hanya saja nasionalisme akan lebih muncul dalam bentuk kegiatan yang konkrit misalnya lomba mirip pahlawan, lomba menulis tentang Indonesia. Ibu SS melihat jika nasionalisme hanya di kelas saja maka dampaknya hanya sebentar saja karena akan segera hilang dilupakan oleh siswa.

Ibu NN melihat bahwa Kompetensi Dasar yang ada dalam kurikulum KTSP dan terutama buku teks yang dikeluarkan pemerintah belum mencerminkan keintegrasian. Ibu NN selanjutnya mengatakan bahwa integrasi antarmateri sejarah, geografi, sosiologi dan ekonomi jarang dilakukan di lapangan karena masih fokus pada RPP yang ada sehingga menurutnya integrasi antarmateri baru tercapai jika RPP sudah memadukan antarmateri di IPS.

Hasil pengamatan dalam observasi di kelas-kelas IPS SMP Negeri 4 Kota Bekasi menunjukkan perbedaan antara guru yang berlatarbelakang pendidikan sejarah dengan yang tidak berlatarbelakang pendidikan sejarah ketika memimpin pembelajaran sejarah di kelas IPS. Guru yang berlatar pendidikan sejarah tampak lebih menguasai materi dibandingkan dengan guru yang tidak berlatarbelakang pendidikan sejarah. Guru yang tidak menguasai materi lebih banyak mengandalkan LKS dan buku teks dalam kegiatan pembelajaran sejarah.

Kurangnya penguasaan materi tampak pada kelas Ibu NM di kelas IX.2. Pada saat observasi berlangsung kelas IX.2 sedang membahas G30S/PKI. Ibu NM adalah guru IPS dengan latar belakang pendidikan geografi. Metode yang dipakai guru untuk membahas topik ini adalah diskusi kelompok. Kelompok yang bertugas mempresentasikan topik dan kemudian mengajukan pertanyaan kepada teman-temannya antara lain mengenai nama surat kabar yang dikeluarkan PKI. Kelompok tersebut tidak menjelaskan surat kabar tahun atau 
periode apa yang dimaksud, tidak ada pertanyaan dari guru mengenai hal itu. Siswa yang ditunjuk untuk menjawab tidak dapat menjawab pertanyaan. Pertanyaan akhirnya dijawab sendiri oleh kelompok. Tidak terlihat usaha guru untuk memberi penguatan atau penekanan atas jawaban-jawaban yang diberikan. Tanya-jawab yang berlangsung berjalan hampir tanpa ada peran guru yang hanya berdiri di belakang kelas.

Di kelas Ibu NM seperti yang tergambar di atas menunjukkan siswa yang presentasi tampak bersemangat dalam memaparkan topik sejarah yang ditugaskan padanya. Meskipun begitu, suasana pembelajaran yang menarik yang membangkitkan rasa ingin tahu siswa tidak terbangun karena penguasaan materi guru kurang memadai.

Suasana berbeda terjadi di kelas Ibu SS yang mempunyai latar belakang pendidikan sejarah seperti yang tergambar dalam catatan catatan lapangan di kelas VIII.6. Pada saat memasuki kelas Ibu SS memberitahu siswa mengenai Penyebaran Berita Proklamasi. Guru membuat tabel di whiteboard yang berisi halhal yang berhubungan dengan proklamasi kemerdekaan Indonesia. Siswa diminta untuk mengisi whiteboard sambil mengatakan bahwa yang dapat menjawab benar akan diberi poin sehingga siswa bersemangat mengerjakan tugas. Setelah siswa selesai mengerjakan guru mengevaluasi jawaban siswa sambil memberikan penjelasan. Di akhir pelajaran, guru menugaskan siswa mencari gambar atau foto-foto tokoh yang berperan dalam proklamasi kemerdekaan. Gambaran kelas VIII.6 pada saat observasi menunjukkan bahwa kelas yang diampu oleh Ibu SS sangat hidup karena siswa bersemangat dan antusias. Suasana kelas yang hidup ini sangat didukung oleh penguasaan guru terhadap materi.

\subsection{Tujuan Program}

Kurikulum KTSP menjabarkan mata pelajaran IPS dalam Standar Kompetensi dan Kompetensi Dasar adalah sebagai berikut (Agung, 2015:103-107) 
a. latar belakang

Mengkaji seperangkat peristiwa, fakta, konsep dan generalisasi yang berkaitan dengan isu sosial. Pada jenjang SMP/MTs mata pelajaran IPS berisikan materi geografi, sejarah, sosiologi, dan ekonomi. Melalui mata pelajaran IPS, peserta didik diarahkan untuk dapat menjadi Warga Negara Indonesia yang demokratis dan bertanggungjawab serta warga dunia yang cinta damai.

b. Tujuan

Mata pelajaran IPS bertujuan agar peserta didik mempunyai kemampuan:

1. mengenal konsep-konsep yang berkaitan dengan kehidupan masyarakat dan lingkungannya

2. memiliki kemampuan dasar untuk berpikir kritis dan logis, rasa ingin tahu, inkuiri, memecahkan masalah dan ketrampilan dalam kehidupan sosial

3. memiliki komitmen dan kesadaran terhadap nilai-nilai sosial dan kemanusiaan

4. memiliki kemampuan komunikasi, bekerja sama dan berkompetisi dalam masyarakat yang majemuk, di tingkat lokal, nasional dan global

c. Ruang Lingkup

Ruang lingkup mata pelajaran IPS meliputi aspek-aspek sebagai berikut

1. manusia, tempat dan lingkungan

2. waktu, berkelanjutan dan perubahan

3. sistem sosial dan budaya

4. perilaku ekonomi dan kesejahteraan

Wawancara dan observasi yang dilakukan menunjukkan bahwa tujuan pembelajaran IPS yang tercantum dalam Kurikulum KTSP tidak diketahui secara persis oleh guru-guru IPS. Salah seorang guru yang mengatakan bahwa tujuan IPS adalah untuk mengenal alam yang berarti berkaitan dengan geografi, bersosialisasi yang berarti berkaitan dengan sosiologi, memenuhi kebutuhan 
yang berarti berkaitan dengan ekonomi yang ketika menjelaskannya bersentuhan dengan sejarah.

Guru yang lain mengatakan bahwa tujuan pembelajaran IPS adalah terciptanya manusia Indonesia yang berwatak cinta tanah air dan menjadi manusia yang berguna bagi masyarakat. Jawaban dari guru-guru tersebut menunjukkan masih belum kuatnya pengetahuan dan pemahaman guru mengenai IPS termasuk tujuan pembelajaran IPS di mana sejarah diintegrasikan di dalamnya.

\subsection{Kurikulum}

Semua guru mengalami masa di mana IPS diajarkan secara terpisah-pisah sehingga guru yang latar belakang pendidikannya sejarah mengajar IPS sejarah, guru yang latar belakang pendidikannya geografi mengajar IPS-geografi dan guru yang latar belakang pendidikannya ekonomi mengajar IPS-ekonomi. Akan tetapi sejak diberlakukannya Kurikulum KTSP tahun 2006, guru harus mengajarkan IPS secara terpadu artinya satu orang guru IPS harus mampu mengajarkan materi-materi yang berkaitan dengan sejarah, geografi, ekonomi dan sosiologi sekaligus. Tugas ini diakui oleh Ibu SS sangat berat pada awalnya tetapi Ibu SS berusaha untuk memperdalam .

Menurut Ibu SS yang juga menjabat sebagai koordinator bidang kurikulum mengatakan bahwa Kurikulum KTSP mempunyai kelebihan dan kekurangan. Sebagai guru yang juga bertugas sebagai koordinator bidang kurikulum, Ibu SS merasakan bagaimana sulitnya mengimplementasikan suatu kurikulum di lapangan. Menurutnya Kurikulum KTSP sudah baik hanya saja dibandingkan dengan Kurikulum 2013 tekanannya memang masih pada penilaian kognitif saja meskipun aspek pembentukan karakter menurutnya sudah dengan sendirinya inheren dalam Kurikulum KTSP. Ibu SS sangat khawatir dengan rencana pemberlakuan Kurikulum Nasional yang menurut informasi yang diterimanya akan diberlakukan mulai tahun depan. Ibu SS 
melihat bahwa Sumber Daya Manusia yang ada di SMP Negeri 4 belum siap. Penguasaan IT yang menjadi salah satu aspek yang menonjol dalam Kurikulum Nasional masih sangat lemah karena diperkirakan baru setengah dari guru-guru yang menguasainya. Tidak hanya kendala SDM, SMP Negeri 4 Kota Bekasi juga menghadapi kendala sarana dan prasarana.

Menurut Ibu EH hambatan dalam menerapkan Kurikulum KTSP adalah pada pembuatan RPP. Dikatakannya beberapa kali pernah mengikuti pelatihan mengenai cara membuat RPP IPS terpadu ataupun mengunduhnya dari internet tapi sejauh ini Ibu EH belum pernah mencoba membuat RPP IPS terpadu seperti yang diterimanya dalam pelatihan meskipun menurutnya ketika mencoba mempraktikkannya di lapangan dalam sebuah pelatihan, ternyata Ibu EH dapat mengajar dengan lebih baik. Ibu NN juga merasakan harus berusaha keras melakukan penyesuaian-penyesuaian. Ibu NM yang berlatarbelakang pendidikan ekonomi merasa sangat sulit ketika harus juga mengajar geografi dan sejarah. Ibu NM juga menyiratkan karakteristik ekonomi dan sejarah sangat berbeda sehingga dibutuhkan tenaga ekstra keras untuk menyesuaikan perubahan dalam Kurikulum KTSP yang mengharuskannya juga menguasai materi selain ekonomi dalam IPS. Hambatan yang dihadapi guru dalam Kurikulum KTSP materi yang banyak dengan jumlah waktu yang lebih sedikit dibandingkan dengan kurikulum sebelumnya sebagaimana yang disampaikan oleh Ibu NN.

Ibu NN melihat bahwa bahasan IPS terlalu luas sehingga waktu yang disediakan sebanyak 4 jam dalam seminggu tidak mencukupi untuk IPS meskipun diakui dalam kurikulum KTSP juga telah terjadi penguranganpengurangan. Ibu NM yang merupakan guru IPS yang paling senior di SMP Negeri 4 Kota Bekasi merasa khawatir dengan perubahan kurikulum-kurikulum. Menurutnya Pusat Kurikulum (Puskur) disibukkan dengan teori dan kemudian mengganti kurikulum padahal praktiknya tidak sesuai dengan teorinya. 


\subsection{Buku}

Buku merupakan permasalahan tersendiri dalam pembelajaran IPS di SMP Negeri 4 Kota Bekasi. Sekolah dilarang menjual buku ke siswa sementara bantuan buku dari pemerintah sangat terbatas dan banyak yang rusak setelah dipakai kakak kelas sebelumnya. Pada tahun 2013 pada saat pelaksanaan Kurikulum 2013, pihak SMP Negeri 4 Kota Bekasi sempat menerima kiriman buku-buku teks tetapi kurikulum 2013 hanya diberlakukan selama satu tahun saja dan kembali ke Kurikulum 2006 KTSP.

Ibu SS mengatakan bahwa larangan sekolah untuk menjual buku kepada siswa di sisi lain tidak dibarengi oleh cukupnya buku yang disediakan oleh pemerintah sehingga tidak semua siswa mendapat buku terutama buku-buku IPS sehingga untuk mengatasi masalah tersebut Ibu SS menyarankan siswa meminjam buku dari teman, kakak, atau tetangga. Ibu SS berharap pemerintah memenuhi kebutuhan buku sejumlah siswa bahkan dilebihkan untuk gurugurunya.

Belum meratanya siswa yang memiliki buku teks juga masih ditambah dengan minimnya buku-buku penunjang yang disediakan oleh perpustakaan sekolah. Pembelajaran IPS di kelas pada akhirnya banyak bergantung pada Lembar Kerja Siswa (LKS) yang memang diwajibkan untuk dibeli siswa. Menanggapi mengenai perpustakaan sekolah, Ibu SW mengatakan bahwa sekolah sudah berupaya semaksimal mungkin dengan menambah jumlah koleksi karena memang ada anggarannya setiap tahun atau dengan berupaya mendorong siswa memanfaatkan perpustakaan sekolah.

\subsection{Sarana Prasarana}

SMP Negeri 4 Kota Bekasi berdiri pada 1979 yang berarti lebih tua dari keberadaan Kota Bekasi yang pada 2016 baru berusia sembilan belas tahun. SMP Negeri 4 Kota Bekasi terletak di Jalan Komodo Raya No.2 Perumnas 1 Bekasi Selatan Kota Bekasi sehingga dari lokasinya dapat diketahui bahwa SMP Negeri 4 Kota Bekasi ini terletak di daerah yang cukup strategis di Kota Bekasi karena 
relatif dekat dengan pusat pemerintahan dan perekonomian Kota Bekasi. Jumlah guru yang mengajar di SMP Negeri 4 Kota Bekasi berjumlah 53 orang dengan jumlah siswa hampir mencapai 1400 orang dibagi dalam 30 rombel yang terdiri dari 10 kelas IX, 9 kelas VIII, dan 11 kelas VII. SMP Negeri 4 Kota Bekasi mempunyai luas 10.860 M2 yang merupakan SMP Negeri terluas se-Kota Bekasi sehingga sering menjadi tempat diselenggarakannya rapat-rapat di lingkungan dinas pendidikan Kota Bekasi.

Pada saat dilakukan penelitian terlihat perbaikan gedung sekolah tengah berlangsung. Beberapa ruang kelas tampak telah selesai diperbaiki sementara sebagian lagi tampak belum diselesaikan pengerjaannya sehingga tampak terbengkalai, sedangkan pemasangan conblock di sebagian lapangan sekolah masih berlangsung. Satu hal yang sangat menganggu dari lokasi sekolah adalah tempat pembuangan sampah sementara yang ada persis di sisi timur sekolah yang cukup mengganggu, meskipun sejak Februari 2016 telah ditutup, sesekali aroma sampah tercium di kelas-kelas yang bersebelahan.

Selain kelas-kelas, SMP Negeri 4 Kota Bekasi juga mempunyai lapangan olahraga yang cukup memadai, perpustakaan terletak di lantai dua sekolah dalam kondisi cukup baik. Buku-buku yang disediakan perpustakaan masih belum memadai meskipun setiap tahunnya ada penambahan buku-buku. SMP Negeri 4 Kota Bekasi juga memiliki laboratorium IPA tetapi dibongkar dan sampai saat ini laboratorium IPA belum dibangun kembali. Untuk sarana ibadah, sebuah masjid yang cukup luas juga dibangun di SMP Negeri 4 Kota Bekasi. Ruang kelas yang ada di SMP Negeri 4 Kota Bekasi dipakai oleh 40-44 siswa sehingga ruangan cukup penuh untuk ruangan berukuran $30 \mathrm{~m} 2$ dan juga terasa panas pada siang hari. Kipas angin disediakan di tiap ruang kelas tapi tidak semuanya berfungsi. Ketersediaan LCD masih sangat minim di SMP Negeri 4 Kota Bekasi karena hanya tersedia dua buah yang melayani 30 rombel. Tahun depan, sekolah berencana menambah 6-7 buah LCD lagi. Hampir sama dengan dengan Ibu SW, Ibu EH mengatakan bahwa sekolah sudah cukup 
menyediakan sarana prasarana yang dibutuhkan seperti peta dan buku hanya saja memang untuk LCD jumlahnya sangat terbatas padahal jika LCD jumlahnya memadai Ibu NN yakin pelajaran IPS akan lebih menarik, lebih tepat waktu terutama yang berkaitan dengan materi sejarah.

\subsection{Kompetensi Guru IPS}

Lama mengajar guru-guru IPS di SMP Negeri 4 Kota Bekasi bervariasi dari yang sudah 34 tahun sampai 11 tahun. Latar belakang pendidikan guru IPS juga bervariasi yaitu Ibu SS dari S1 Pendidikan Sejarah, Ibu NM dan EH dari S1 Pendidikan Geografi, Ibu NN dari S1 Ekonomi Koperasi Ibu DS dari S1 Pendidikan Ekonomi/Manajemen. Satu orang orang guru IPS tersebut merupakan pindahan yaitu Ibu EH merupakan guru pindahan dari SMP Negeri 1 Pahaijulu Tapanuli Utara. Semua guru IPS di SMP Negeri 4 Kota Bekasi sudah mengajar IPS sejak awal karir mereka kecuali ibu DS baru 5 tahun terakhir mengajar IPS karena sebelumnya mengajar ketrampilan. Informasi mengenai lama mengajar memberitahukan bahwa mereka telah mengalami beberapa kali pergantian kurikulum.

Latar belakang 5 guru IPS di SMP Negeri 4 Kota Bekasi sudah sesuai dengan kriteria dan karenanya telah mendapat sertifikasi guru. Tiga dari lima orang guru sekarang sedang menyelesaikan pendidikan Strata 2 Program Studi Pendidikan IPS di Universitas Indrapasta Jakarta. Satu orang dari guru IPS yaitu Ibu SS dipercaya sebagai bagian kurikulum sedangkan satu orang guru IPS lainnya yaitu Ibu NM merupakan ketua koperasi guru di SMP Negeri 4 Kota Bekasi.

\section{Transactions}

\subsection{Perencanaan Pembelajaran}

Guru IPS di SMP Negeri 4 Kota Bekasi telah membuat Rencana Pelaksanaan Pembelajaran (RPP) sebelum proses pembelajaran di kelas. Semua guru mengerjakan sendiri pembuatan RPP dengan sistematika pembuatan RPP yang sesuai dimulai dari informasi mengenai nama sekolah, mata pelajaran, 
kelas/semester, standar kompetensi, kompetensi dasar, dan alokasi waktu. Pada bagian berikutnya dituliskan indikator, tujuan pembelajaran, materi ajar, metode pembelajaran, langkah-langkah kegiatan, metode pembelajaran, sumber belajar dan penilaian hasil pembelajaran.

2.2 Pelaksanaan Kegiatan Pembelajaran

Guru-guru IPS di SMP Negeri 4 Kota Bekasi melaksanakan sebagian besar Rencana Pelaksanaan Pembelajaran (RPP) yang dimilikinya di kelas. Observasi yang dilakukan memang menunjukkan terkadang sulit bagi guru untuk menerapkan RPP-nya karena berbagai kendala misalnya waktu. Ketika guru harus masuk kelas, sering terjadi guru lain masih belum selesai sehingga memakan waktu yang dimilikinya.

Masalah lain yang dihadapi guru dalam pelaksanaan pembelajaran adalah minat siswa yang rendah pada pembelajaran sejarah yang terintegrasi dalam mata pelajaran IPS menjadi gejala umum di SMP Negeri 4 Kota Bekasi.

Keterangan yang didapat dari Ibu EH membenarkan bahwa siswa umumnya enggan untuk belajar IPS terutama materi yang berkaitan dengan sejarah. Alasan yang diajukan siswa mengenai ketidaksukaannya kepada sejarah adalah banyaknya hafalan dalam sejarah. Siswa menganggap sejarah sulit dicerna karena mempelajari sesuatu yang sudah berlalu terlalu abstrak bagi sebagian siswa seperti topik-topik yang berkaitan dengan kerajaan-kerajaan masa HinduBudha atau masa Islam. Sementara geografi lebih mudah dicerna siswa karena topik-topik yang diketengahkan seperti gunung atau dataran tinggi dan rendah langsung dapat dilihat keberadaannya oleh siswa.

Siswa yang dimintai konfirmasi mengenai pernyataan bahwa pelajaran IPS tidak menarik, peneliti mendapat pernyataan dari tiga orang siswa $C, K$, dan Y dari kelas VIII yang justru mengatakan bahwa pelajaran IPS menarik. Siswa C, $\mathrm{K}$, dan $\mathrm{Y}$ mengatakan memang menyenangi materi-materi yang berkaitan dengan sejarah dan geografi hanya memang ketiganya membenarkan bahwa 
kesulitan yang dihadapi dalam mempelajari IPS terutama sejarah adalah kegiatan menghafal.

Ibu SS berpendapat bahwa mindset atau pola pikir siswa, orang tua dan masyarakat terhadap IPS-lah yang menyebabkan mata pelajaran IPS kurang diminati siswa. Ada tendensi dari siswa untuk mengutamakan mata pelajaranmata pelajaran yang di-UN-kan saja. Mata pelajaran IPS dianggap tidak relevan dengan dunia kerja ditambah dengan sarana prasarana yang belum memadai sehingga mata pelajaran IPS semakin tidak menarik. Guru IPS lain, Ibu NN menanggapi pernyataan bahwa mata pelajaran IPS tidak disukai siswa di SMP Negeri 4 Kota Bekasi.

Penjelasan Ibu NN menggambarkan bahwa sebagian anak suka pelajaran IPS tetapi sebagian lagi tidak suka pelajaran IPS. Sebagian anak yang dikatakan Ibu NN menyukai sejarah melihat sejarah hanya cerita masa lalu yang tidak bermakna. Siswa yang lain melihat sejarah seperti dongeng sebelum tidur sehingga membuat mereka mengantuk. Ibu NN menambahkan bahwa sebenarnya anak-anak menyukai film sebagai media pembelajaran sejarah tetapi tempat untuk menonton film sekarang dibongkar.

Pengamatan di kelas-kelas IPS memang ada tampak kecendrungan keengganan siswa dalam mengikuti pembelajaran IPS seperti yang terjadi di kelas IX.2 pada 16 Februari 2016 yang diajar oleh Ibu NM. Pembelajaran IPS tersebut berlangsung tidak kondusif antara lain disebabkan suara bising dari luar kelas akibat pembangunan sekolah. Situasi pembelajaran sejarah yang tidak menarik dan membosankan juga terjadi di kelas IX.5 dan IX.6. Hal berbeda terjadi dalam pembelajaran sejarah yang diampu oleh Ibu SS yang mempunyai latar belakang sejarah, pengamatan menunjukkan proses pembelajaran berjalan cukup menarik bagi siswa.

Pada saat berkesempatan berbincang, Ibu DS mengeluhkan efek negatif kemajuan teknologi yang menurutnya justru membuat siswa malas membaca termasuk dalam mata pelajaran IPS yang diampunya. Ibu DS juga mengeluhkan 
kecendrungan siswa termasuk orang tua siswa sekarang yang bersikap santai dan merasa tanpa beban karena kebijakan sekolah gratis. Menurutnya kemajuan teknologi dan kebijakan sekolah gratis menyebabkan motivasi belajar siswa menjadi rendah.

Rendahnya minat membaca siswa juga diakui oleh Ibu SW wakil kepala sekolah yang mengakui bahwa budaya membaca kurang dimiliki siswa padahal menurutnya IPS dan terutama sejarah menuntut banyak kemauan membaca dari siswa. Menurutnya rendahnya budaya membaca di kalangan siswa disebabkan anak-anak sekarang mau yang serba instan, tidak mau mencari sendiri. Lebih jauh lagi Ibu SW juga menduga bahwa rendahnya budaya baca disebabkan gurunya juga kurang suka membaca seperti yang diakuinya terjadi pada dirinya yang semakin hari semakin kurang membaca.

\subsection{Metode Pembelajaran}

Ibu SW mengatakan bahwa guru-guru IPS sebenarnya sudah cukup berusaha membuat variasi dalam pembelajaran IPS misalnya dengan menayangkan film-film sejarah menumpang di lab IPA. Sayangnya lab IPA sekarang dibongkar sehingga tidak lagi dapat dimanfaatkan oleh IPS sehingga menyulitkan. Terhadap kinerja guru-guru IPS, Ibu SW menilai cukup bagus semua guru IPS di SMP Negeri 4 Kota Bekasi meskipun terdapat satu orang yang latar belakangnya bukan IPS sehingga tidak pernah diberi tugas mengajar di kelas IX.

Observasi di lapangan menunjukkan bahwa metode diskusi cukup dominan dilakukan guru-guru di kelas. Akan tetapi jumlah siswa yang banyak dalam satu kelas sering menyebabkan pelaksanaan diskusi kurang efektif karena guru menjadi kurang dapat mengontrol alur diskusi. Keributan menjadi tidak terhindarkan, perhatian guru menjadi terpecah antara memperhatikan presentasi yang dibawakan kelompok penyaji dan peserta diskusi. 


\subsection{Media Pembelajaran}

Media pembelajaran yang sering digunakan di kelas-kelas IPS di SMP Negeri 4 Kota Bekasi adalah whiteboard. Media peta sesekali dipergunakan seperti yang dilakukan Ibu NM di kelasnya ketika membahas materi upaya perebutan Irian Barat. Keinginan guru untuk menggunakan media LCD terkendala oleh keterbatasan alat tersebut di sekolah yang hanya berjumlah dua buah padahal animo beberapa guru IPS untuk dapat memproyeksikan tayangan lewat LCD sangat besar.

\subsection{Penilaian Proses Pembelajaran}

Guru-guru IPS di SMP Negeri 4 Kota Bekasi melaksanakan penilaian hasil belajar kepada siswa. Penilaian proses dilaksanakan pada kegiatan pembelajaran di kelas. Ibu SS mengatakan bahwa nilai IPS di kelas yang diampunya baik.

Pada saat observasi, Ibu SS memang senantiasa memberikan nilai selama proses pembelajaran berlangsung dengan sistem poin. Siswa yang dianggap melakukan kegiatan positif seperti melakukan tugas, menjawab pertanyaan akan diberikan poin-poin.

Guru-guru IPS yang lain pada saat diobservasi tidak melakukan penilaian proses pembelajaran sejarah. Pada saat wawancara mengatakan bahwa penilaian proses umumnya dilakukan sewaktu-waktu. Ibu wakasek SW mengatakan bahwa secara umum nilai IPS siswa SMP Negeri 4 Kota Bekasi biasa-biasa saja artinya tidak terlalu meningkat secara signifikan juga tidak rendah.

\section{Outcomes}

\subsection{Hasil}

Hasil yang diharapkan pada komponen outcomes adalah dipenuhinya Kriteria Ketuntasan Minimal untuk mata pelajaran IPS. Pada ujian kenaikan kelas yang berlangsung pada Mei 2016 diketahui bahwa rata-rata nilai ujian IPS untuk kelas VII adalah 7,85, untuk kelas VIII adalah 7,56 dan untuk kelas IX 
adalah 7,65. Hasil yang ditunjukkan oleh siswa pada mata pelajaran IPS menunjukkan bahwa Kriteria Ketuntasan Minimal sebesar 7,5 telah terlampaui meskipun tidak melampaui terlalu tinggi.

Salah seorang guru, Ibu DS mengatakan bahwa tidak masuknya IPS menjadi mata ujian dalam Ujian Nasional menyebabkan siswa menyepelekan mata pelajaran IPS sehingga ketika menghadapi ujian siswa malas belajar.

3.2 Dampak

Dampak yang diharapkan dari pembelajaran sejarah yang terintegrasi dalam mata pelajaran IPS adalah dicapainya sikap dan perilaku siswa yang sesuai dengan tujuan pembelajaran sejarah yaitu berpikir sejarah dan cinta tanah air. Berpikir sejarah adalah kemampuan berpikir runtut secara kronologis yang mengkonsepsikan kehidupan dalam perjalanan waktu. Pengamatan di lapangan menunjukkan bahwa dampak pembelajaran sejarah yang terintegrasi dalam mata pelajaran IPS di SMP Negeri 4 Kota Bekasi belum dapat mencapai kemampuan berpikir sejarah karena guru masih banyak menggali tingkat kognitif mengingat dan memahami belum menyentuh pada tingkat analisis. Siswa menganggap sejarah adalah sesuatu yang tidak mempunyai makna dan hanya perlu dihafal. Ibu NM secara langsung mengatakan bahwa jarang ada anak yang suka sejarah karena seperti yang pernah diceritakan salah satu siswa langsung kepadanya yang tidak menyukai pelajaran sejarah karena merasa tidak ada gunanya mempelajari masa lalu. Menurut Ibu NM banyak siswa tidak menyukai sejarah karena banyak menghafal waktu, tanggal, bulan dan materi yang terlalu banyak.

Serupa dengan dampak berpikir sejarah yang diharapkan, tumbuhnya rasa cinta tanah air juga diharapkan tumbuh dari pembelajaran sejarah. Ibu guru SS mengatakan bahwa sebenarnya pembelajaran sejarah yang terintegrasi dalam mata pelajaran IPS dapat mewadahi pemupukan rasa cinta tanah air tetapi hal tersebut akan lebih efektif lagi jika ditunjang dengan kegiatan-kegiatan yang konkrit dalam kegiatan ekstrakurikuler seperti lomba mirip pahlawan, lomba 
menulis tentang Indonesia. Menurut Ibu SS jika hanya mengandalkan pembelajaran sejarah di kelas maka sama saja seperti memberi nasehat akan hilang. Ibu SS dalam kegiatan pembelajaran di kelas pernah meminta siswa mementaskan drama mengenai salah satu tokoh pahlawan atau meminta siswa menuliskan hal-hal yang menarik mengenai Indonesia.

\section{PEMBAHASAN}

Isu yang mengemuka dalam mata pelajaran IPS di SMP Negeri 4 Kota Bekasi adalah bagaimana mata pelajaran IPS dapat diintegrasikan dengan 4 bidang yaitu geografi, sejarah, ekonomi dan sosiologi. Meskipun telah beberapa kali mengikuti pelatihan guru merasa belum mengerti betul konsep integrasi dan yang terpenting adalah bagaimana mengintegrasikan keempat bidang tersebut dalam IPS.

Tidak ada panduan-panduan yang cukup jelas bagi guru mengenai keintegrasian dalam IPS. Guru-guru berpendapat bahwa tidak semua hal dapat diintegrasikan dalam IPS. Masalah terbesar dalam menerapkan keintegrasian dalam IPS di SMP Negeri 4 Kota Bekasi adalah latar belakang pendidikan guru yang berasal dari salah satu dari empat bidang dalam IPS yaitu guru yang berasal dari geografi, ekonomi dan sejarah. Hasil pengamatan dan wawancara dengan guru menunjukkan bahwa latar belakang pendidikan guru sangat berpengaruh pada cara guru melakukan pendekatan dalam pembelajarannya.

Sejak diberlakukannya Kurikulum KTSP tahun 2006, guru harus mengajarkan IPS secara terpadu artinya satu orang guru IPS harus mampu mengajarkan materi-materi yang berkaitan dengan sejarah, geografi, ekonomi dan sosiologi. Perubahan kurikulum sangat mengkhawatirkan bagi guru karena menganggap kemampuan setiap guru berbeda. Kekhawatiran para guru di SMP Negeri 4 Kota Bekasi dilihat dari ketersediaan sarana dan prasarana sekolah cukup beralasan. 
Kekhawatiran lain guru-guru IPS di SMP Negeri 4 Kota Bekasi adalah luasnya cakupan pembahasan dalam IPS dalam kurikulum meskipun dalam kurikulum KTSP diakui telah terjadi pengurangan-pengurangan.Luasnya cakupan membuat guru merasa kesulitan dalam memenuhi kurikulum yang mengalokasikan waktu 2X80 menit perminggunya. Observasi di lapangan mengkonfirmasi sekaligus mendiskonfirmasi kekhawatiran tersebut. Waktu 2X80 menit perminggu memang terlihat sedikit untuk memenuhi 3-4 Standar Kompetensi yang masing-masing mempunyai 2-4 Kompetensi Dasar yang harus dirinci lagi dalam indikator-indikator. Pada akhirnya guru-guru hanya fokus pada terpenuhinya aspek kognitif dari setiap Kompetensi Dasar. Observasi di lapangan menunjukkan pengelolaan waktu guru masih perlu diperhatikan karena waktu untuk IPS sebanyak 80 menit untuk setiap pertemuan pada praktiknya tidak dimanfaatkan secara maksimal dengan berbagai alasan atau kendala. Concern yang besar juga diberikan kepada ketersediaan sarana dan prasarana yang mendukung pembelajaran IPS. Ketersediaan buku teks yang belum mencukupi menjadi kekhawatiran terbesar dari guru-guru IPS. Kebijakan pemerintah melarang sekolah menjual buku, membuat siswa sepenuhnya bergantung pada pengadaan buku teks dari pemerintah padahal jumlahnya sangat terbatas.

Ketersediaan LCD di sekolah juga tampak mendesak untuk ditambah karena jumlah yang hanya dua buah di sekolah sangat tidak memadai. Sulit untuk guru atau siswa untuk membuat tayangan powerpoin untuk mempresentasikan materi atau juga untuk menayangkan film yang akan sangat menarik khususnya untuk materi sejarah.Pada akhirnya ketersediaan sarana dan prasarana harus pula ditunjang oleh kemampuan IT guru sehingga dapat memaksimalkan kemampuan teknologi dalam menunjang suatu pembelajaran yang efektif dan efisien.

Kurang diminatinya IPS terutama pada materi sejarah menjadi gejala umum yang dirasakan oleh guru-guru IPS termasuk pihak sekolah di SMP 
Negeri 4 Kota Bekasi. Penyebab kurang diminatinya IPS terutama materi sejarah adalah Siswa menganggap terlalu banyak hafalan dalam materi sejarah. Pelajaran sejarah identik dengan hafalan terkonfirmasi di SMP Negeri 4 Kota Bekasi. Siswa-siswa yang diwawancarai mengatakan kesulitan dalam IPS termasuk dalam mempelajari sejarah adalah terlalu banyak hafalan terutama hafalan yang berkaitan dengan tahun-tahun dan tokoh-tokoh. Hasil pengamatan di lapangan mengkonfirmasi pernyataan para siswa bahwa sejarah terlalu banyak hafalan. Di kelas-kelas IPS yang mengetengahkan materi-materi sejarah mulai kelas VII-IX, semua guru tampak masih mengorganisasikan pembelajaran pada ranah kognitif level paling rendah yaitu mengingat, sehingga pertanyaanpertanyaan yang muncul adalah berputar pada siapa, apa dan kapan yang tentu saja membutuhkan ingatan atau hafalan. Jarang sekali guru menanyakan pertanyaan aspek ke"mengapa"an yang jawabannya membutuhkan tingkat kognisi yang lebih tinggi dari ingatan. Maka pembelajaran sejarah di kelas-kelas IPS di SMP Negeri 4 Kota Bekasi tidak menarik karena siswa menganggap sejarah adalah pelajaran menghafal tanpa ada suatu pemahaman mengenai apa yang dihafalnya tersebut seperti yang diungkapkan siswa pada saat wawancara.

Guru dalam mengajarkan sejarah seringkali dibingungkan dan terjebak oleh kronologi dan antikuarisme (mempelajari masa lampau untuk masa lampau itu sendiri). Pemikiran kronologis (chronological thinking) adalah suatu yang penting dalam pembelajaran sejarah tetapi merupakan bagian dari proses untuk memahami suatu perubahan dari waktu ke waktu dari suatu fenomena. Pada praktiknya pemikiran kronologis disamakan dengan susunan kronologis (chronological order) yang berimplikasi pada keharusan linearitas dan hafalan tanpa unsur interpretasi. Guru seharusnya mengidentifikasi tonggak-tonggak penting (key turning points) agar dapat berlaku adil pada masa lalu dan agar siswa ikut terlibat dalam pembelajaran sejarah. Untuk itu guru harus membangun batasan (base line) (Drake\&Nelson, 2005:16-19). 
Hasil pengamatan pembelajaran sejarah dalam mata pelajaran IPS di SMP Negeri 4 Kota Bekasi menunjukkan bahwa guru IPS dalam pembelajaran sejarah tidak memperhatikan konsep penting dalam sejarah yaitu waktu dan perubahan. Sebagai contoh dalam satu kelas yang diobservasi guru menjelaskan Peristiwa Madiun 1948 dan Peristiwa G30S/PKI, tidak tampak adanya perbedaan antara dua peristiwa yang terjadi pada periode yang berbeda. Guru menjelaskan kedua peristiwa tersebut digerakkan oleh komunis, tetapi guru tidak menjelaskan konteks peristiwa yang sangat berbeda satu sama lain. Peristiwa Madiun 1948 berlatarbelakang zaman revolusi kemerdekaan dan Peristiwa G30S/PKI berlatarbelakang Orde Lama. Guru hanya menekankan bahwa komunis memberontak, kejam karena ingin merongrong Negara Kesatuan Republik Indonesia. Guru tidak berusaha menjelaskan pemikiran kronologis yang tidak hanya menjelaskan aspek waktu tetapi juga perubahan dan interpretasi. Sulit membangun suasana pembelajaran yang menarik, menantang dan mendorong pemikiran kritis bagi siswa.

\section{Outcomes}

Hasil yang diharapkan pada komponen outcomes adalah dipenuhinya Kriteria Ketuntasan Minimal untuk mata pelajaran IPS. Hasil yang ditunjukkan oleh siswa pada mata pelajaran IPS menunjukkan bahwa Kriteria Ketuntasan Minimal sebesar 7,5 telah terlampaui meskipun tidak melampaui terlalu tinggi.

Berpikir sejarah adalah kemampuan berpikir runtut secara kronologis yang mengkonsepsikan kehidupan dalam perjalanan waktu. Pengamatan di lapangan menunjukkan bahwa dampak pembelajaran sejarah yang terintegrasi dalam mata pelajaran IPS di SMP Negeri 4 Kota Bekasi belum dapat mencapai kemampuan berpikir sejarah karena guru masih banyak menggali tingkat kognitif mengingat dan memahami belum menyentuh pada tingkat analisis. Siswa menganggap sejarah adalah sesuatu yang tidak mempunyai makna dan hanya perlu dihafal. 
Tumbuhnya rasa cinta tanah air juga diharapkan tumbuh dari pembelajaran sejarah. Akan tetapi sulit mengharapkan tumbuhnya rasa cinta tanah air muncul jika siswa masih menganggap bahwa sejarah adalah sekadar untuk dihapal dan tidak berguna bagi kehidupannya karena hanya merupakan kisah masa lalu tanpa makna.

\section{KESIMPULAN}

Berdasarkan uraian dan hasil analisis data penelitian evaluasi terhadap program pembelajaran sejarah yang terintegrasi dalam mata pelajaran IPS di SMP Negeri 4 Kota Bekasi, maka dapat disimpulkan guru belum mengerti sepenuhnya konsep integrasi dan belum melaksanakannya di kelas-kelas IPS. Latar belakang pendidikan guru sangat berpengaruh pada cara guru dalam melakukan pendekatan dalam pembelajarannya. Guru merasa lebih mudah dan percaya diri jika mengajar sesuai dengan latar belakang pendidikannya. Muncul kekhawatiran bahwa perubahan-perubahan kurikulum akan semakin memperberat kerja guru. Perubahan kurikulum dianggap masih pada tataran teoretis yang sulit untuk diterapkan di lapangan. Kekhawatiran lain guru-guru IPS di SMP Negeri 4 Kota Bekasi adalah luasnya cakupan bahasan dalam IPS dalam kurikulum.

Buku merupakan permasalahan tersendiri dalam pembelajaran IPS di SMP Negeri 4 Kota Bekasi. Sekolah dilarang menjual buku ke siswa sementara bantuan buku dari pemerintah sangat terbatas. Sarana Prasarana di SMP Negeri 4 Kota Bekasi terus mengalami perbaikan dari tahun ke tahun seperti ruang kelas. Hal yang mendesak untuk diperhatikan pihak sekolah adalah pengadaan LCD di kelas-kelas yang masih sangat minim jumlahnya.

Kompetensi guru IPS di SMP Negeri 4 Kota Bekasi sudah memadai karena berlatarbelakang disiplin rumpun IPS. Guru IPS di SMP Negeri 4 Kota Bekasi telah membuat Rencana Pelaksanaan Pembelajaran (RPP) sebelum proses pembelajaran di kelas. Semua guru mengerjakan sendiri pembuatan RPP dengan 
sistematika pembuatan RPP yang sesuai meskipun RPP yang dihasilkan belum memenuhi RPP IPS yang telah terintegrasi. metode diskusi cukup dominan dilakukan guru-guru di kelas. Namun begitu, guru-guru IPS telah berupaya untuk memberikan metode pembelajaran yang bervariasi. Media pembelajaran yang sering digunakan di kelas-kelas IPS di SMP Negeri 4 Kota Bekasi adalah whiteboard. Media peta sesekali dipergunakan. Guru-guru IPS di SMP Negeri 4 Kota Bekasi melaksanakan penilaian hasil belajar kepada siswa. Penilaian proses dilaksanakan pada kegiatan pembelajaran di kelas.

Hasil yang diharapkan pada komponen outcomes adalah dipenuhinya Kriteria Ketuntasan Minimal untuk mata pelajaran IPS. Hasil ujian kenaikan kelas menunjukkan bahwa siswa SMP Negeri 4 Kota Bekasi memenuhi KKM bahkan rata-rata di atas KKM berada sedikit di atas nilai KKM. Dampak yang diharapkan dari pembelajaran sejarah yang terintegrasi dalam mata pelajaran IPS adalah dicapainya sikap dan perilaku siswa yang sesuai dengan tujuan pembelajaran sejarah yaitu berpikir sejarah dan cinta tanah air. Pengamatan di lapangan menunjukkan bahwa dampak pembelajaran sejarah yang terintegrasi dalam mata pelajaran IPS di SMP Negeri 4 Kota Bekasi belum dapat mencapai kemampuan berpikir sejarah. Tumbuhnya rasa cinta tanah air juga diharapkan dikembangkan dari pembelajaran sejarah yang dilaksanakan di SMP Negeri 4 Kota Bekasi tetapi bukti nyata sikap cinta tanah air ini belum terlihat nyata.

\section{DAFTAR PUSTAKA}

[1] Abma, Tineke A. (2005)." Responsive Evaluation Its Meaning and Special Contribution to Health Promotion" dalam Journal Evaluation and Program Planning (28), Elsevier.

[2] Arifin, Zainal. (2013) Evaluasi Pembelajaran, Bandung:PT Remaja Rosdakarya.

[3] Agung, Leo., Wahyuni, Sri. (2013) Perencanaan Pembelajaran Sejarah, Yogyakarta: Penerbit Ombak. 
[4] Agung, Leo. (2015). Sejarah Kurikulum Sekolah Menengah di Indonesia Sejak Kemerdekaan Hingga Reformasi, Yogyakarta:Penerbit Ombak. "Implementasi Model Pembelajaran Terpadu (Suatu Studi Evaluatif di SMP Kota Surakarta)" dalam Jurnal Pendidikan dan Kebudayaan Vol.18 No.2 Juni 2012.

[6] Creswell, John. (2015). Riset Pendidikan:Perencanaan, Pelaksanaan, dan Evaluasi Riset Kualitatif dan Kuantitatif Edisi Kelima, terjemahan Helly Prajitno Soetjipto dan Sri Mulyantini Soetjipto, Yogyakarta:Pustaka Pelajar.

[7] Drake, Frederick D., Nelson, Lynn R. (2005). Engagement in Teaching History Theory and Secondary Teachers, New Jersey:Pearson.

[8] Gagne, Robert M., et.all. (2005). Principle of Instructional Design 5th, Boston: Wadsworth Thompson Learning.

[9] Guba, Egon G, Lincoln, Yvonne S. (1981). Effective Evaluation: Improving the Usefulness of Evaluation Results through Responsive and Naturalistic Approaches, San Fransisco CA: Jossey Bass.

[10] Hasan, Hamid. (2012). Pendidikan Sejarah Indonesia: Isu dalam Ide dan Pembelajaran, Bandung:Rizqi Press.

[11] Kartodirdjo, Sartono. (2014) Pendekatan Ilmu Sosial Dalam Metodologi Sejarah, Yogyakarta: Ombak.

[12] Kuntowijoyo. (2005). Pengantar Ilmu Sejarah, Yogyakarta: Bentang.

[13] Rachmah, Huriah. (2014). Pengembangan Profesi Pendidikan IPS, Bandung: Alfabeta.

[14] Sapriya. (2014). Pendidikan IPS: Konsep dan Pembelajaran, Bandung:PT Remaja Rosdakarya.

[15] Stake, Robert E. Program Evaluation Particularly Responsive Evaluation (1973), http://education.illinois.edu/circe/publications/responsive_eval.pdf (diakses 18 Desember 2015)

[16] Sanjaya, Wina. (2014). Strategi Pembelajaran Berorientasi Standar Proses Pendidikan, Jakarta:Kencana Prenada Media.

[17] Susanto, Ahmad. (2014). Pengembangan Pembelajaran IPS di Sekolah Dasar, Jakarta:Prenada Media Grup. 
[18] Trianto. (2015). Model Pembelajaran Terpadu:Konsep, Strategi dan Implementasinya dalam Kurikulum Tingkat Satuan Pendidikan (KTSP), Jakarta: PT Bumi Aksara.

[19] Wineburg, Sam. (2006). Berpikir Historis Memetakan Masa Depan, Mengajarkan Masa Lalu, Jakarta: Yayasan Obor Indonesia. 